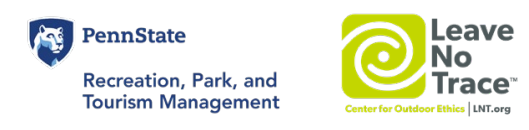

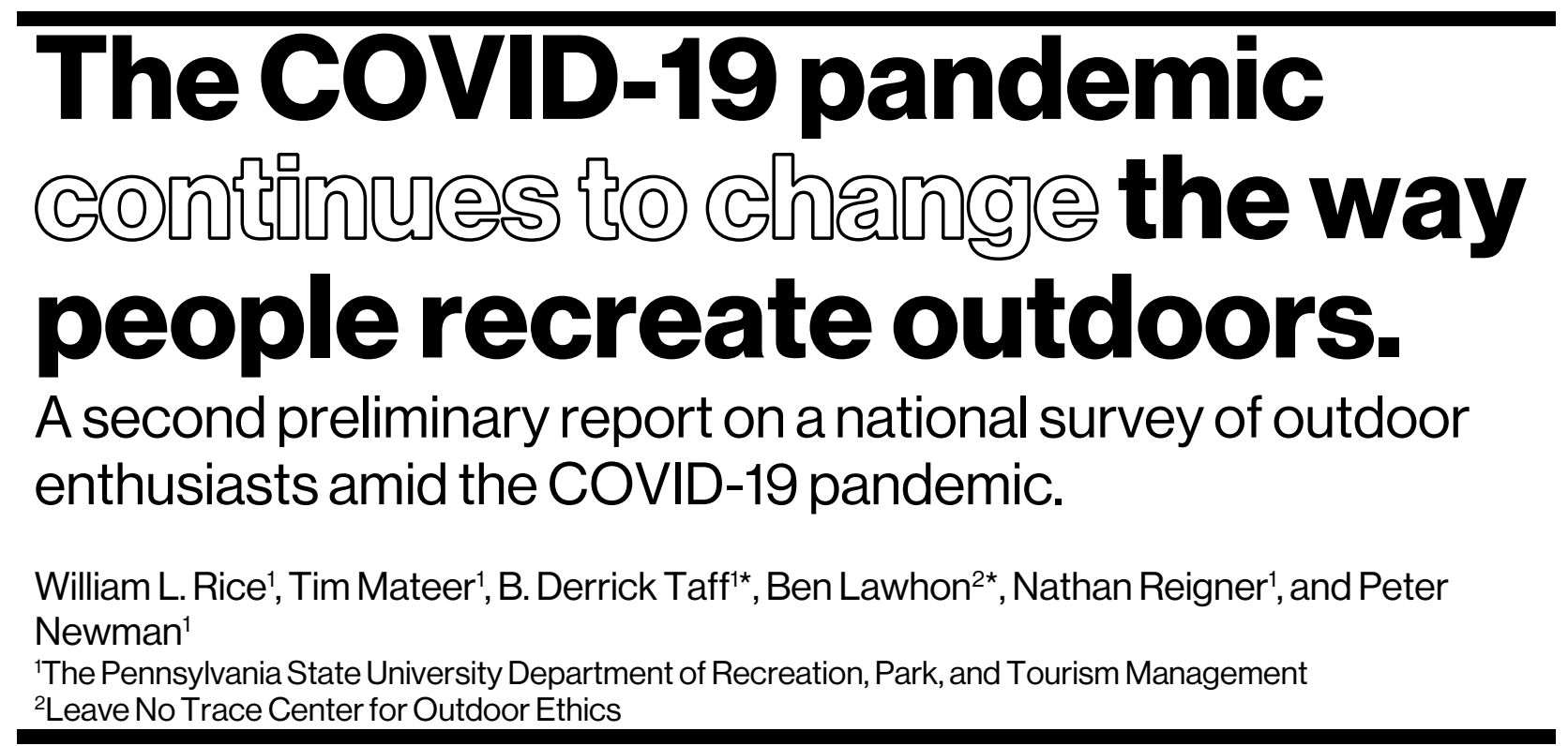

The COVID-19 pandemic continues to alter daily life and lead to changes in the way we spend time outside. In an effort to gather timely and relevant data on national recreation patterns before, during, and after the pandemic, the Leave No Trace Center for Outdoor Ethics and its academic partner, Pennsylvania State University, have been working to conduct a study that can offer guidance to land managers, recreation providers, and outdoor enthusiasts across the United States. Phase 1 of this assessment was conducted April $9^{\text {th }}-11^{\text {th }}, 2020$ (Rice et al., 2020). Phase 2 of this assessment was conducted April $30^{\text {th }}-$ May $2^{\text {nd }}$. This second phase of research - discussed in this preliminary report - was designed to provide additional information regarding changes in recreation trends since April $9^{\text {th }}$, which provides valuable information for managing dynamic recreational use on public lands. In total, 823 outdoor recreationists were surveyed through the Leave No Trace community in a 48-hour window beginning on the morning of April $30^{\text {th }}$. The results of this second rapid assessmentcomplete with comparisons to Phase 1 data-will provide valuable information for managing the changing recreation use of public lands, predicting spikes in recreation, and offering insight for land managers as they work to protect the natural world.

The following tables, figures, and corresponding brief descriptions are intended to provide initial results from Phase 2 of our research effort, with comparisons to Phase 1 when appropriate. Further results are forthcoming.

Please note that not all respondents answered all questions.

*Corresponding Authors: ben@Int.org (B. Lawhon) and bdt3@psu.edu (B. D. Taff) 


\section{Sample Demographics.}

\section{Response Rate:}

63,864 recipients within the Leave No Trace Center for Outdoor Ethics' email listserv

8,046 recipients opened the email containing the survey link

823 recipients completed the survey

25.4\% completed Phase 1 survey

\section{Gender:}

Female: $57.0 \%$

Male: $39.6 \%$

Transgender: $0.6 \%$

Non-binary: $1.2 \%$

Other: $0 \%$

Prefer not to say: $1.5 \%$
Age:

Mean: 47 years old

Standard deviation: 15.6 years

\section{Residency:}

U.S. residents: $97.4 \%$

Non-U.S. residents: $2.6 \%$

Table 1: Community of Residence

\begin{tabular}{lll}
\hline Community with a population of... & Frequency & Percent \\
\hline Less than 5,000 (rural area) & 205 & $31.5 \%$ \\
Between 5,000 and 50,000 (urban cluster) & 164 & $25.2 \%$ \\
More than 50,000 (urban area) & 282 & $43.3 \%$ \\
\hline
\end{tabular}

Adapted from U.S. Census Bureau (2010)

Figure 1: Spatial Distribution of Responses within the Contiguous United States* 
${ }^{*}$ Darker gradients indicate more responses

Ethnicity:

White: $89.4 \%$

Hispanic or Latina/Latino/Latinx: $2.6 \%$

Asian or Pacific Islander: $2.0 \%$

Black or African American: 0.3\%

Native American, American Indian, or Alaska Native: 0.0\%

Other: $2.5 \%$

Prefer not to say: $3.1 \%$

\section{Income:}

$\leq \$ 20,000: 7.4 \%$

$\$ 21,000-\$ 40,000: 14.3 \%$

$\$ 41,000-\$ 60,000: 17.8 \%$

$\$ 61,000-\$ 80,000: 13.6 \%$

$\$ 81,000-\$ 100,000: 14.6 \%$

$>\$ 100,000: 32.3 \%$

\section{Employment:}

Currently employed: $60.6 \%$

Currently not working: $39.4 \%$

Currently unemployed in response to the COVID-19 pandemic: $15.7 \%$

\section{Personal impacts of COVID-19:}

Friend or family member diagnosed with COVID-19 16.0\%

Personally know someone in community diagnosed with COVID-19 $32.7 \%$

Personally know someone who has died from COVID-19 $11.7 \%$

Suspect to have personally contracted COVID-19 at any point $\quad 19.5 \%$

Personally diagnosed with COVID-19 $\quad 0.2 \%$

Personally hospitalized because of COVID-19 0.0\%

\section{Perceptions of Risk.}

Table 2: Perceptions of Personal and Community Risk

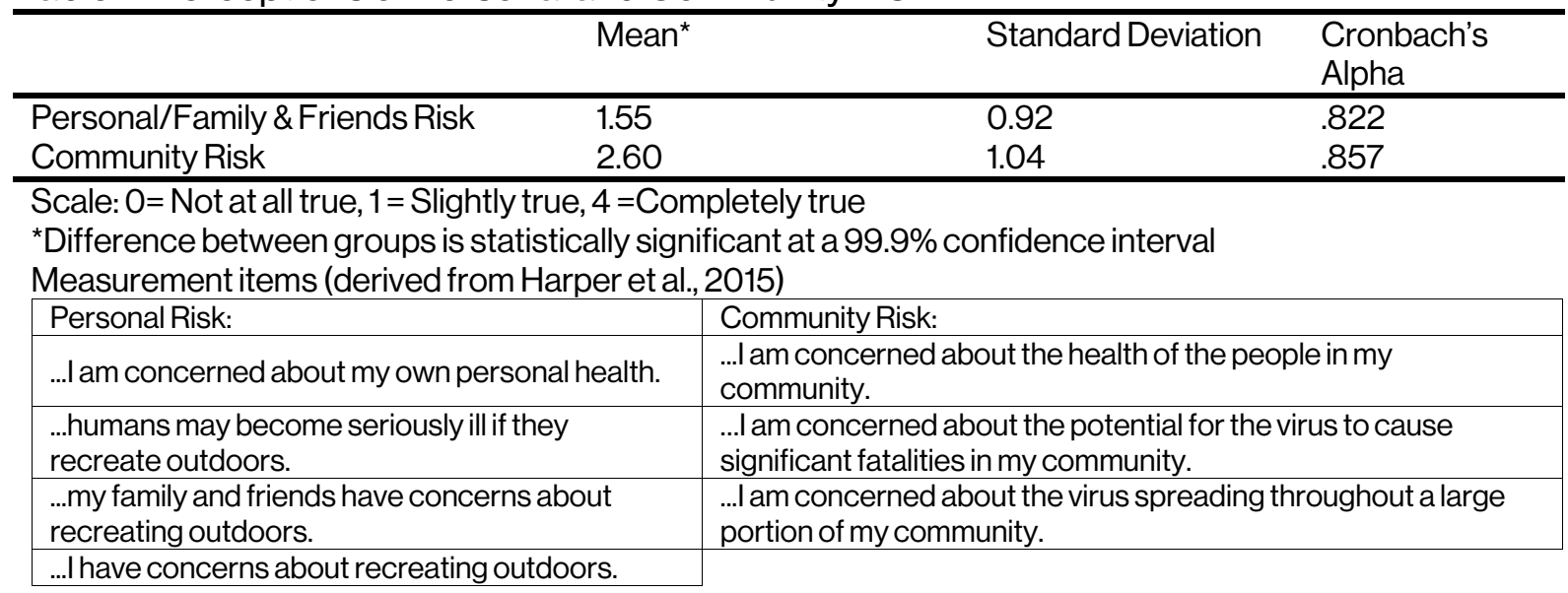

Table 3: How much risk do you feel from becoming ill from COVID-19?

\begin{tabular}{l|llll}
\hline & No risk & Slight risk & Moderate Risk & High Risk \\
\hline Frequency & 42 & 334 & 251 & 64 \\
\hline
\end{tabular}




\begin{tabular}{l|llll}
\hline$\%$ & 6.1 & 48.3 & 36.3 & 9.3 \\
\hline
\end{tabular}

Overall, respondents were significantly more concerned about risks to their larger communities than to themselves or friends and family (Table 2). Respondents generally felt slight to moderate risk of becoming ill from COVID-19 (Table 3).

\section{Trust in Agencies.}

Table 4: Trust in information and decision-making of health and public lands agencies

\begin{tabular}{|c|c|c|c|}
\hline & \multicolumn{2}{|r|}{ Standard Deviation } & $\begin{array}{l}\text { Cronbach's } \\
\text { Alpha }\end{array}$ \\
\hline \multicolumn{4}{|l|}{ Information* } \\
\hline $\begin{array}{l}\text { State health agencies and the } \\
\text { Centers for Disease Control }\end{array}$ & 2.42 & 1.05 & .927 \\
\hline $\begin{array}{l}\text { State and federal public land } \\
\text { management agencies }\end{array}$ & 2.22 & 1.05 & .958 \\
\hline \multicolumn{4}{|l|}{ Decision-making* } \\
\hline $\begin{array}{l}\text { State health agencies and the } \\
\text { Centers for Disease Control }{ }^{1}\end{array}$ & \multicolumn{2}{|l|}{2.31} & .920 \\
\hline $\begin{array}{l}\text { State and federal public land } \\
\text { management agencies }\end{array}$ & 2.21 & 1.09 & .953 \\
\hline \multicolumn{4}{|c|}{$\begin{array}{l}\text { *Difference between groups is statistically significant at a 99.9\% confidence interval } \\
\text { 'Statistically significant difference at a } 99 \% \text { confidence interval (Bonferroni corrected) based on perceived } \\
\text { personal risk level (Table 3). Post-hoc tests reveal "No Risk" group less trusting than other groups at a 95\% } \\
\text { confidence interval. } \\
\text { Scale: } 0=\text { Not at all true, } 1=\text { Slightly true, } 2 \text { = Moderately true, } 3=\text { Very true, } 4 \text { =Completely true } \\
\text { Measurement items (derived from Harper et al., 2015): }\end{array}$} \\
\hline \multicolumn{2}{|l|}{\begin{tabular}{|l} 
Information: \\
\end{tabular}} & \multicolumn{2}{|l|}{ Decision-making: } \\
\hline \multicolumn{2}{|c|}{$\begin{array}{l}\text {...provide me with enough information to decide what actions I } \\
\text { should take regarding outdoor recreation during the COVID-19 } \\
\text { pandemic. }\end{array}$} & \multicolumn{2}{|c|}{$\begin{array}{l}\text {...make good decisions regarding outdoor } \\
\text { recreation management the COVID-19 pandemic. }\end{array}$} \\
\hline \multicolumn{2}{|c|}{$\begin{array}{l}\text {...provide me with the best available information regarding } \\
\text { outdoor recreation during the COVID-19 pandemic. }\end{array}$} & \multicolumn{2}{|c|}{$\begin{array}{l}\text {...follow the best available science in managing } \\
\text { outdoor recreation during the COVID-19 } \\
\text { pandemic. }\end{array}$} \\
\hline \multicolumn{2}{|c|}{$\begin{array}{l}\text {...provide me with timely information regarding outdoor } \\
\text { recreation during the COVID-19 pandemic. }\end{array}$} & \multicolumn{2}{|c|}{...properly address the COVID-19 pandemic. } \\
\hline
\end{tabular}

Respondents are slightly more trusting of state health agencies and the Centers for Disease Control (CDC) for the dissemination of information and decision-making related to outdoor recreation during the COVID-19 pandemic, compared to state and federal public land agencies (Table 4). Respondents who perceived themselves as at no risk of illness from COVID-19 (Table 3) were significantly less trusting of health agencies. It is important for public agencies to incorporate CDC recommendations in their information-sharing and decision-making. 


\section{Expected Operational Safety Practices for Public Land Recreation Management.}

Table 5: What operational practices do you expect public land agencies to implement in response to the COVID-19 pandemic?

\begin{tabular}{|c|c|c|}
\hline \multirow[t]{2}{*}{ 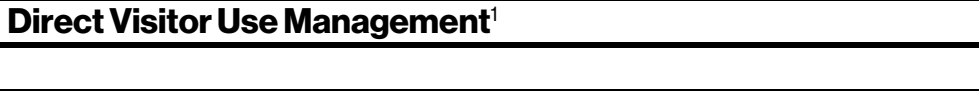 } & & \multirow{2}{*}{$\begin{array}{l}\text { Cronbach's Alpha }=.858 \\
\text { Standard Deviation }\end{array}$} \\
\hline & Mean* & \\
\hline Implement capacity limits & 3.07 & 1.08 \\
\hline Use timed entries (whether through entrance gates, trailheads, etc.) & 2.58 & 1.26 \\
\hline Enforce social distancing & 2.50 & 1.33 \\
\hline Require visitors to wear masks & 2.45 & 1.43 \\
\hline $\begin{array}{l}\text { Use body temperature checks when visitors enter the premises at } \\
\text { high use areas }\end{array}$ & 2.29 & 1.39 \\
\hline Use body temperature checks when visitors enter the premises & 1.71 & 1.36 \\
\hline $\begin{array}{l}\text { Require certificate of immunity (signed by licensed physician) due } \\
\text { to the fact that a visitor has recovered from an infection or has been } \\
\text { vaccinated (once vaccines are available) }\end{array}$ & 1.14 & 1.27 \\
\hline Index & 2.25 & 0.96 \\
\hline \multirow[t]{2}{*}{ Indirect Visitor Use Management $^{1}$} & & Cronbach's Alpha $=.824$ \\
\hline & Mean* & Standard Deviation \\
\hline Have policies to manage crowds & 3.41 & 0.89 \\
\hline Provide hand sanitizer in high traffic areas & 3.19 & 1.00 \\
\hline $\begin{array}{l}\text { Place signage encouraging people to stay six feet apart from one } \\
\text { another in high traffic areas }\end{array}$ & 3.07 & 1.13 \\
\hline Encourage visitors to wear masks & 3.02 & 1.17 \\
\hline $\begin{array}{l}\text { Place indicators on paths to remind visitors to stay six feet apart in } \\
\text { normally crowded areas }\end{array}$ & 2.62 & 1.31 \\
\hline Provide disinfectant wipes in high traffic areas & 2.55 & 1.33 \\
\hline $\begin{array}{l}\text { Provide visitors with personal protective equipment (e.g., gloves, } \\
\text { masks) }\end{array}$ & 1.56 & 1.31 \\
\hline Index & 2.78 & 0.82 \\
\hline \multirow[t]{2}{*}{ Workforce and Facility Management ${ }^{1}$} & & Cronbach's Alpha $=.820$ \\
\hline & Mean $^{\star}$ & Standard Deviation \\
\hline $\begin{array}{l}\text { Provide employees with personal protective equipment (e.g., } \\
\text { gloves, masks) }\end{array}$ & 3.56 & 0.79 \\
\hline Increased sanitation practices in all public areas & 3.51 & 0.79 \\
\hline Clearly communicate their increased sanitation practices & 3.36 & 0.90 \\
\hline Require employees to wear masks & 3.01 & 1.12 \\
\hline Install shields/barriers between visitors and employees & 2.65 & 1.23 \\
\hline Use body temperature checks when employees start their shifts & 2.25 & 1.25 \\
\hline Install shields/barriers between visitor and visitor (e.g., in line) & 1.54 & 1.31 \\
\hline Index & 2.84 & 0.74 \\
\hline
\end{tabular}

*Scale: $0=$ Not at all agree, 1 = Slightly agree, 4 =Completely agree

'Statistically significant difference at a 99\% confidence interval (Bonferroni corrected) based on

perceived personal risk level (Table 3). Post-hoc tests reveal general trend of statistically significant 
increase in expected implementation as perceived risk increases.

Items adapted from University of Florida Tourism Crisis Management Initiative (2020)

Respondents had higher levels of expectations for public land agencies' indirect and workforce/facility-related management strategies than direct strategies to combat COVID19. Interestingly, respondents moderately agreed that the direct management strategies of carrying capacities and timed entry should be implemented on public lands in response to COVID-19. Strong agreement was found for public lands agencies providing and requiring employees to use personal protective equipment (e.g., masks and gloves), providing hand sanitizer to visitors, increasing sanitation practices, and communication details about increased sanitation practices. Those at higher perceived risk of illness from COVID-19 had significantly higher expectations across direct, indirect, and workforce/facility management.

\section{Support for tourist visitation.}

Table 6: How supportive are you to open your community to tourists...

\begin{tabular}{lll}
\hline & Mean $^{*}$ & Standard Deviation \\
\hline ....with no restrictions? & -0.88 & 1.11 \\
...f there are restrictions on & 0.50 & 1.00 \\
capacity? & & \\
\hline
\end{tabular}

Scale: -2 = Extremely unsupportive, 0 = Neither supportive or unsupportive, 2 = Extremely supportive

${ }^{*}$ Difference between groups is statistically significant at a 95\% confidence interval

'Statistically significant difference at a 99\% confidence interval (Bonferroni corrected) based on perceived personal risk level (Table 3). Post-hoc tests reveal general trend of statistically significant decrease in support as perceived risk increases.

Items adapted from University of Florida Tourism Crisis Management Initiative (2020)

Respondents were unsupportive, on average, of opening their communities to tourists with no restrictions and slightly supportive, on average, with restrictions (Table 6). Those at higher perceived risk of illness from COVID-19 were significantly less supportive of opening under with restrictions.

\section{Change in Frequency of Outdoor Recreation.}

Table 7: Change in the amount of days per week in which respondents participated in outdoor recreation

\begin{tabular}{|c|c|c|}
\hline & $\begin{array}{l}\text { Phase1: } \\
\text { Change from March } 11^{\text {th }}-\text { April } 9^{\text {th }}(n=1117)\end{array}$ & $\begin{array}{l}\text { Phase 2: } \\
\text { Change from April } 9^{\text {th }}-\text { April } 30^{\text {th }}(n=820)\end{array}$ \\
\hline $\begin{array}{l}\text { Mean Change } \\
\text { of Days* }\end{array}$ & -.32 days & +0.02 days \\
\hline
\end{tabular}

The COVID-19 pandemic continues to change the way people recreate outdoors. 
The Phase 1 survey (Rice et al., 2020) revealed that frequency of outdoor recreation participation decreased slightly among the surveyed population from March $11^{\text {th }}$ to April $9^{\text {th }}$. The Phase 2 survey revealed that participation remained nearly constant from April $9^{\text {th }}$ to April $30^{\text {th }}$ (Table 7 ). This evidence suggests that change in frequency of outdoor recreation has largely plateaued among the population.

\section{Changes to Time of Outdoor Recreation.}

Table 8: Have you changed the time of day you participate in outdoor recreation?

\begin{tabular}{lll}
\hline & $\begin{array}{l}\text { Phase 1: April } 9^{\text {th }} \text { Survey }(n=947) \\
(\ldots \text { ince March 11 }\end{array}$ & $\begin{array}{l}\text { Phase 2: April 30 } \\
(\ldots \text { th }\end{array}$ \\
\hline Yes Survey $(n=660)$ & $39.1 \%$ \\
No & $46.5 \%$ & $60.9 \%$ \\
\hline
\end{tabular}

The Phase 1 survey revealed that nearly half of the surveyed population changed the time of day they participate in outdoor recreation from March $11^{\text {th }}$ to April $9^{\text {th }}$ in response to the COVID-19 pandemic. The Phase 2 survey revealed that the time of participation remains in flux, as $39.1 \%$ of respondents reported a change since April $9^{\text {th }}$ (Table 8). However, this smaller change may indicate that changes in this behavior may be starting to plateau.

\section{Distance Traveled to Participate in Outdoor Recreation.}

Table 9: Distance travelled by respondents to participate in outdoor recreation

\begin{tabular}{|c|c|c|c|c|c|c|c|}
\hline & & & 0-2 Miles & 3-5 miles & 6-15 miles & $16-50$ miles & $>50$ miles \\
\hline & In the month prior to & Frequency & 102 & 109 & 187 & 295 & 240 \\
\hline$\Phi$ & $(n=933)$ & $\%$ & 10.9 & 11.7 & 20.0 & 31.6 & 25.7 \\
\hline$\frac{\pi}{\alpha}$ & $\begin{array}{l}\text { March 11th to April 9 } 9^{\text {th }} \\
(n=877)\end{array}$ & Frequency & 440 & 167 & 169 & 81 & 20 \\
\hline & & $\%$ & 50.2 & 19.0 & 19.3 & 9.2 & 2.3 \\
\hline & $\begin{array}{l}\text { In the } 3 \text { weeks prior to } \\
\text { April 9th }\end{array}$ & & 180 & 151 & 164 & 139 & 77 \\
\hline 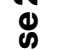 & $(n=711)$ & $\%$ & 25.3 & 21.2 & 23.1 & 19.5 & 10.8 \\
\hline$\frac{\pi}{\alpha}$ & $\begin{array}{l}\text { Since April 9 }{ }^{\text {th }} \\
(\mathrm{n}=698)\end{array}$ & & 290 & 177 & 141 & 73 & 17 \\
\hline & & $\%$ & 41.5 & 25.4 & 20.2 & 10.5 & 2.4 \\
\hline
\end{tabular}

Table 10: Change in average distance travelled between Phase 1 and Phase 2 surveys

\begin{tabular}{|c|c|c|}
\hline & $\begin{array}{l}\text { Phase1: } \\
\text { Change from March } 11^{\text {th }}-\text { April } 9^{\text {th }}(n=871)\end{array}$ & $\begin{array}{l}\text { Phase 2: } \\
\text { Change from April } 9^{\text {th }}-\text { April } 20^{\text {th }}(n=685)\end{array}$ \\
\hline $\begin{array}{l}\text { Mean Change of } \\
\text { Distance Travelled* }\end{array}$ & -1.54 scale points & -0.62 scale points \\
\hline
\end{tabular}


${ }^{\star}$ Difference between groups is statistically significant at a 99\% confidence interval

Scale: $1=0-2$ miles, 2 = 3-5 miles, $3=6-15$ miles, $4=16-50$ miles, $5=>50$ miles

Phase 1 respondents decreased distance travelled to participate in outdoor recreation from March $11^{\text {th }}$ to April $9^{\text {th }}$ (Table 9). Phase 2 respondents also decreased distance traveled, however there is an inconsistency in distance reported over largely the same time period between March $11^{\text {th }}$ and April $9^{\text {th }}$ (Phase 1) and the three weeks prior to April $9^{\text {th }}$ (Phase 2). Differences in average change during Phase 1 and Phase 2 are significantly different (Table 10). The significantly smaller change in distance travelled seen in Phase 2 may indicate that changes in travel behavior are beginning to plateau.

\section{Change in Outdoor Recreation Area Use.}

Table 11: Average change in use among respondents for various land and water designations

\begin{tabular}{|c|c|c|}
\hline & \multicolumn{2}{|c|}{ Average Change in Use $^{+}$} \\
\hline & $\begin{array}{l}\text { Phase 1: April 9th Survey } \\
\left(\ldots \text { since March } 11^{\text {th }}\right)\end{array}$ & $\begin{array}{l}\text { Phase 2: April 30th Survey } \\
\text { (...since April 9 } 9^{\text {th }} \text { ) }\end{array}$ \\
\hline Private land or waters ${ }^{\star \star \star}$ & $-0.68 x^{1}$ & $-0.17 x^{1}$ \\
\hline Neighborhood or city streets & $+0.92 x^{2}$ & $+1.10 x^{2}$ \\
\hline City or town parks ${ }^{*}$ & $-0.85 x^{3}$ & $-0.54 x$ \\
\hline County or regional parks $s^{\star \star *}$ & $-1.15 x$ & $-0.72 x$ \\
\hline Land trust or conservancy lands* & $-1.07 x^{1}$ & $-0.85 x$ \\
\hline State Parks ${ }^{\star *}$ & $-1.58 x^{1}$ & $-1.27 x$ \\
\hline State Forests* & $-1.35 x^{1}$ & $-1.01 x$ \\
\hline State Game Management lands & $-1.04 x^{1}$ & $-.089 x$ \\
\hline National Forests** & $-1.38 x^{1}$ & $-1.09 x$ \\
\hline Bureau of Land Management lands ${ }^{\star \star}$ & $-1.18 x^{1}$ & $-0.89 x$ \\
\hline National Wildlife Refuges ${ }^{\star \star}$ & $-1.19 x^{1}$ & $-0.90 x$ \\
\hline Army Corps of Engineers recreation areas* & $-0.94 x$ & $-0.70 x$ \\
\hline National Park Service sites ${ }^{\star *}$ & $-1.62 x^{1}$ & $-1.36 x$ \\
\hline Wilderness Areas** & $-1.28 x^{1}$ & $-0.97 x$ \\
\hline Ocean** & $-1.05 x^{1}$ & $-0.75 x$ \\
\hline
\end{tabular}

${ }^{* * *}$ Difference between groups statistically significant at a $99.9 \%$ confidence interval

${ }^{* *}$ Difference between groups statistically significant at a $99 \%$ confidence interval

*Difference between groups statistically significant at a 95\% confidence interval

'Statistically significant difference (95\% confidence) among communities of residence (urban areas decreased more than rural areas)

${ }^{2}$ Statistically significant difference (95\% confidence) among communities of residence (urban areas increased more than rural areas)

${ }^{3}$ Statistically significant difference ( $95 \%$ confidence) among communities of residence (urban areas decreased less than rural areas)

+"Please indicate by what amount you have changed your use of the following types of recreation areas."

For all designations - excluding neighborhood or city streets - respondents decreased use across both Phase 1 and Phase 2. In Phase 1, this decrease was more pronounced among urban area residents than rural residents. Increased use of neighborhood or city streets 
continued across Phases 1 and 2. For most designations, differences between the magnitude of changes in use were significantly different in Phases 1 and 2. The smaller changes in magnitude seen in Phase 2 may indicate that change in use is beginning to plateau.

\section{Change in Outdoor Recreation Group Size.}

Table 12: Average outdoor recreation group size

\begin{tabular}{|c|c|c|c|}
\hline & & Average group size & Standard Deviation \\
\hline \multirow{2}{*}{$\begin{array}{l}\bar{\Phi} \\
\Phi \\
\mathbb{\Phi} \\
\overline{\mathbf{\Phi}}\end{array}$} & In the month prior to March $11^{\text {th }}(n=943)$ & 5.81 people & 10.35 \\
\hline & March 11th to April $9^{\text {th }}(n=940)$ & 1.85 people & 1.08 \\
\hline \multirow{2}{*}{$\begin{array}{l}\text { N } \\
\Phi \\
\mathscr{D} \\
\mathbb{\Phi} \\
\frac{\mathbf{\alpha}}{\alpha}\end{array}$} & In the 3 weeks prior to April $9^{\text {th }}(n=724)$ & 3.30 people & 6.46 \\
\hline & Since April $9^{\text {th }}(n=720)$ & 2.15 people & 5.63 \\
\hline
\end{tabular}

Table 13: Change in average group size between Phase 1 and Phase 2

\begin{tabular}{ll}
\hline & Mean Change in Group Size \\
\hline Phase1: & -3.76 people \\
Change from March $11^{\text {th }}-$ April $9^{\text {th }}(n=940)$ & -1.16 people \\
Phase $2:$ & \\
Change from April $9^{\text {th }}-$ April $20^{\text {th }}(n=718)$ & \\
\hline${ }^{*}$ Difference between groups is statistically significant at a 99.9\% confidence interval
\end{tabular}

Similar to reported changes in distance travelled to participate in outdoor recreation (Table 9), there is an inconsistency in outdoor recreation group size reported over largely the same time period between March $11^{\text {th }}$ and April $9^{\text {th }}$ (Phase 1) and the three weeks prior to April $9^{\text {th }}$ (Phase 2) (Table 12). However, it is still noted that average group size decreased in both phases. Differences in the size of changes in Phase 1 and Phase 2 are significantly different (Table 13). Additionally, the latter period within Phase 1 not only has the smallest average group size, but also the smallest standard deviation. The rebound in group size during Phase 2 indicates that perhaps outdoor enthusiasts are beginning to relax their social distancing behaviors. 


\section{Backcountry Distance Traveled During Outdoor Recreation.}

Table 14: Approximate distance from roads ventured for outdoor recreation activities

\begin{tabular}{|c|c|c|c|}
\hline & & Average miles traveled & Standard Deviation \\
\hline \multirow{2}{*}{$\begin{array}{l}\bar{\Phi} \\
\Phi \\
\mathbb{8} \\
\bar{\square}\end{array}$} & In the month prior to March $11^{\text {th }}(n=780)$ & 4.77 miles & 2.97 \\
\hline & March 11th to April $9^{\text {th }}(n=728)$ & 2.61 miles & 2.49 \\
\hline \multirow{2}{*}{ 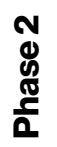 } & In the 3 weeks prior to April $9^{\text {th }}(n=613)$ & 3.49 miles & 2.60 \\
\hline & Since April $9^{\text {th }}(n=594)$ & 2.71 miles & 2.47 \\
\hline
\end{tabular}

Table 15: Change in average distance from roads ventured between Phase 1 and Phase 2 Mean Change in Backcountry Travel ${ }^{*}$

\begin{tabular}{ll}
\hline Phase1: & -2.23 miles $^{1}$ \\
Change from March $11^{\text {th }}-$ April $9^{\text {th }}(n=645)$ & -0.80 miles \\
Phase 2: & \\
Change from April $9^{\text {th }}-$ April $20^{\text {th }}(n=556)$ & \\
\hline *Difference between phases is statistically significant at a $99.9 \%$ confidence interval \\
'Statistically significant difference (95\% confidence) among communities of residence (urban areas \\
decreased less than rural areas)
\end{tabular}

Table 14 reports average distance travelled from roads during outdoor recreation among respondents within the two respective periods of Phase 1 and Phase 2 . Average distance travelled beyond roads decreased significantly less during Phase 2 , but continued to decline (Table 15). Additionally, while urban residents' backcountry behaviors were significantly more impacted than rural residents in Phase 1, they were not significantly more impacted in during Phase 2. 


\section{Psychosocial Factors Influencing Outdoor Recreation Decisions.}

Table 16: Importance of various items when making outdoor recreation decisions measured during Phase 2

\begin{tabular}{|c|c|c|}
\hline $\begin{array}{l}\text { How important are the following } \\
\text { factors when making outdoor } \\
\text { recreation decisions (e.g. frequency } \\
\text { of outing, distance from home, } \\
\text { activity) during the COVID-19 } \\
\text { pandemic? }\end{array}$ & Mean $^{*}$ & Standard Deviation \\
\hline $\begin{array}{l}\text { How severe I perceive the COVID-19 } \\
\text { pandemic to be in the area I am } \\
\text { recreating. }{ }^{1}\end{array}$ & 3.56 & 1.21 \\
\hline $\begin{array}{l}\text { How likely I believe I am to contract } \\
\text { COVID- } 19 \text { while participating in my } \\
\text { outdoor recreation activity. }\end{array}$ & 3.27 & 1.35 \\
\hline $\begin{array}{l}\text { The likelihood that I will } \\
\text { unintentionally spread COVID-19 to } \\
\text { others while recreating outdoors. }\end{array}$ & 3.50 & 1.33 \\
\hline $\begin{array}{l}\text { The outdoor recreation behaviors of } \\
\text { my friends or family. }\end{array}$ & 3.28 & 1.30 \\
\hline $\begin{array}{l}\text { The outdoor recreation behaviors of } \\
\text { my neighbors and surrounding } \\
\text { community. }\end{array}$ & 3.36 & 1.24 \\
\hline $\begin{array}{l}\text { The discussion I see on social media } \\
\text { about recreating outdoors during the } \\
\text { COVID-19 pandemic. }\end{array}$ & 2.78 & 1.31 \\
\hline $\begin{array}{l}\text { The behavioral recommendations } \\
\text { provided by the Center for Disease } \\
\text { Control. }{ }^{3}\end{array}$ & 4.00 & 1.06 \\
\hline $\begin{array}{l}\text { The behavioral recommendations } \\
\text { provided by the World Health } \\
\text { Organization. }{ }^{3}\end{array}$ & 3.72 & 1.23 \\
\hline $\begin{array}{l}\text { The orders and regulations of my } \\
\text { state of residence regarding allowed } \\
\text { behavior during the COVID-19 } \\
\text { pandemic. }{ }^{3}\end{array}$ & 4.14 & 0.98 \\
\hline $\begin{array}{l}\text { Recommendations from land } \\
\text { management agencies regarding } \\
\text { outdoor recreation during the } \\
\text { COVID-19 pandemic. }{ }^{3}\end{array}$ & 3.98 & 1.07 \\
\hline $\begin{array}{l}\text { The open/closed status of public } \\
\text { lands or public lands facilities. }{ }^{3}\end{array}$ & 4.32 & 0.97 \\
\hline $\begin{array}{l}\text { The desire to support my physical } \\
\text { health through exercise. }{ }^{4}\end{array}$ & 4.30 & 0.85 \\
\hline $\begin{array}{l}\text { The desire to support my overall } \\
\text { health by spending time in the } \\
\text { outdoors. }\end{array}$ & 4.44 & 0.76 \\
\hline
\end{tabular}




\begin{tabular}{lll}
\hline $\begin{array}{l}\text { The desire to relieve stress and } \\
\text { support my mental health. }\end{array}{ }^{4}$ & 4.37 & 0.86 \\
\hline $\begin{array}{l}\text { To fill the time I normally spent doing } \\
\text { other recreation activities that I }\end{array}$ & 3.06 & 1.30 \\
cannot do during the COVID-19 \\
pandemic.
\end{tabular}

Table 17: Scales of psychosocial factors influencing outdoor recreation decisions during the COVID-19 pandemic measured during Phase 2

\begin{tabular}{lll}
\hline & Mean & Cronbach's Alpha \\
\hline Perceived Risk & 3.44 & $0.82^{\star \star}$ \\
Social Norms & 3.14 & $0.73^{\star *}$ \\
Orders from Authority & 4.03 & $0.87^{\star \star}$ \\
Health Benefits & 4.37 & $0.85^{\star \star}$ \\
Substitution & 3.34 & $0.71^{\star \star}$ \\
\hline
\end{tabular}

*Scale: 1 = Not at all important, 2=Slightly Important, 3=Moderately Important, 4=Very Important, 5 =

Extremely important

${ }^{\star *}$ Beyond adequate reliability (Vaske, 2008)

Table 18: Results from repeated measures ANOVA examining psychosocial factors influencing outdoor recreation decisions measured during Phase 2

\begin{tabular}{lll}
\hline Mauchly's W & $\mathrm{p}$-value & Huynh-Feldt Epsilon \\
\hline 0.616 & $<0.01$ & $0.796^{*}$ \\
\hline Omnibus Test & F-Statistic & $\mathrm{p}$-value \\
\hline & 282.867 & $<0.001$ \\
\hline Scale Mean Comparisons & Mean Difference & $\mathrm{p}$-value ${ }^{\star *}$ \\
\hline Perceived Risk-Social Norms & 0.305 & $<0.001$ \\
\hline Perceived Risk-Orders from Authority & -0.587 & $<0.001$ \\
\hline Perceived Risk-Health Benefits & -0.924 & $<0.001$ \\
\hline Perceived Risk-Substitution & 0.101 & 0.621 \\
\hline Social Norms-Orders from Authority & -0.892 & $<0.001$ \\
\hline Social Norms-Health Benefits & -1.229 & $<0.001$ \\
\hline Social Norms-Substitution & -0.204 & $<0.001$ \\
\hline Orders from Authority-Health Benefits & -0.337 & $<0.001$ \\
\hline Orders from Authority-Substitution & 0.688 & $<0.001$ \\
\hline Health Benefits-Substitution & 1.025 & $<0.001$ \\
\hline
\end{tabular}

${ }^{*}$ Huynh-Feldt correction utilized due to violation of assumption of sphericity

**Bonferroni adjustment applied to account for multiple comparisons 
Table 19: Comparison of psychosocial scale means between Phase 1 and Phase 2 via independent t-tests

\begin{tabular}{llll}
\hline & Mean Phase One & Mean Phase Two $^{\star}$ & p-value \\
\hline Perceived Risk & 3.6072 & 3.4449 & 0.002 \\
Social Norms & 3.2976 & 3.1399 & 0.002 \\
Orders from Authority & 4.1783 & 4.0316 & $<0.001$ \\
Health Benefits & 4.3166 & 4.3689 & 0.156 \\
Substitution & 3.3853 & 3.3439 & 0.380 \\
\hline
\end{tabular}

*Scale: 1 = Not at all important, 2=Slightly Important, 3=Moderately Important, 4=Very Important, 5=Extremely

${ }^{* *}$ Bonferroni adjustment applied to account for multiple comparisons $(p<0.01)$

In parallel to Phase 1 findings, when making outdoor recreation decisions (e.g. where to go, group size, activity), respondents rated the importance of benefits to mental and physical health significantly more than any of the other measured factors (Tables 16 and 17). Developed scales were grounded in relevant academic literature on psychosocial factors influencing outdoor recreation. This includes perceptions of risk (Green et al., 2009; Reis et al., 2012), messages from authority (Marion \& Reid, 2007), social norms (Heberlein, 2012), health benefits (Kuo, 2015), and substitution processes (Hammit et al., 2004). Reliability analyses during Phase 1 showed all scales were appropriately reliable with Cronbach's Alpha scores greater than 0.65 (Vaske, 2008). Furthermore, a confirmatory factor analysis demonstrated appropriate fit with the following statistics: $\mathrm{RMSEA}=0.079$; $\mathrm{SRMR}=0.0594$; $\mathrm{CFI}=0.902$. Orders from authority, both from land managers as well as from state and federal governments, were rated significantly less important than health benefits but significantly more important than all other factors. In contrast to previous findings, perceived risk and substitution were not significantly different from each other but were different from all other variables (Table 18). These two factors were rated below health benefits and orders from authority but above social norms. Social norms had the lowest scale mean and was significantly different than all other measured psychosocial constructs. In comparing scale means between Phase 1 and Phase 2, there was a significant reduction in scores for the following psychosocial constructs: perceived risk, social norms, and order from authority (Table 19).

\section{Likelihood of Returning to Preferred Outdoor Recreation Behavior and Patterns.}

Table 20: How likely are you to continue or return to your preferred recreation behaviors/patterns when you perceive the threat of COVID-19 has become minimal?'

\begin{tabular}{lll}
\hline & Phase 1: April $9^{\text {th }}$ Survey $(\mathrm{n}=946)$ & Phase 2: April 30 \\
\hline Not Survey $(\mathrm{n}=656)$ \\
Slightly likely & $1.2 \%$ & $0.9 \%$ \\
Moderately likely & $3.9 \%$ & $3.2 \%$ \\
Very likely & $10.3 \%$ & $12.2 \%$ \\
Extremely likely & $23.2 \%$ & $24.8 \%$ \\
\hline
\end{tabular}


${ }^{1}$ No statistically significant difference between surveys

Likelihood to continue or return to preferred recreation behaviors/patterns when the perceived threat of COVID-19 becomes minimal did not significantly change between Phase 1 and Phase 2 (Table 20). The majority of respondents remain extremely likely to return to their preferred recreation behaviors and patterns.

\section{Perceived Long-Term Changes in Recreation Behavior.}

Table 21: Do you perceive that your outdoor recreation behavior (i.e., where, when, how, and with whom) will change in the long-term following the World Health Organization's official announcement ending the COVID-19 pandemic?

\begin{tabular}{lll}
\hline & Phase 1: April $9^{\text {th }}$ Survey $(n=944)$ & Phase 2: April $30^{\text {th }}$ Survey $(n=656)$ \\
\hline Yes & $37.7 \%$ & $49.4 \%$ \\
No & $62.3 \%$ & $50.6 \%$ \\
\hline
\end{tabular}

${ }^{*}$ Difference between phases is statistically significant at a $99.9 \%$ confidence interval

Table 22: If yes, please respond by indicating your agreement or disagreement with the following statements.

\begin{tabular}{|c|c|c|}
\hline $\begin{array}{l}\text { Following the World Health } \\
\text { Organization's official } \\
\text { announcement ending the } \\
\text { COVID-19 pandemic, my long- } \\
\text { term outdoor recreation } \\
\text { participation will change from } \\
\text { how I recreated before the } \\
\text { pandemic by... }\end{array}$ & Phase 1: April $9^{\text {th }}$ Survey $(\mathrm{n}=356)$ & Phase 2: April 30 $0^{\text {th }}$ Survey $(n=320)$ \\
\hline $\begin{array}{l}\text {...traveling further than I } \\
\text { previously did to recreate. }{ }^{1}\end{array}$ & 0.07 & 0.24 \\
\hline $\begin{array}{l}\text {...utilizing my local public lands } \\
\text { more often. }\end{array}$ & 0.69 & 0.82 \\
\hline $\begin{array}{l}\text {...participating in more types of } \\
\text { outdoor recreation. }\end{array}$ & 0.66 & 0.66 \\
\hline $\begin{array}{l}\text {...participating in more fitness- } \\
\text { based outdoor recreation } \\
\text { activities. }\end{array}$ & 0.44 & 0.43 \\
\hline $\begin{array}{l}\text {...changing the types of outdoor } \\
\text { recreation I participate in. }{ }^{1}\end{array}$ & 0.13 & 0.35 \\
\hline $\begin{array}{l}\text {...changing the time of day I } \\
\text { recreate. }\end{array}$ & 0.09 & 0.19 \\
\hline $\begin{array}{l}\text {...changing the days of the week I } \\
\text { recreate. }\end{array}$ & 0.19 & 0.21 \\
\hline ...recreating alone more often. & 0.12 & 0.23 \\
\hline
\end{tabular}

Scale: $-2=$ Strongly disagree, 2 = Strongly agree, 0 =Neither agree nor disagree

${ }^{1}$ Statistically significant difference between phases at a $95 \%$ confidence interval 
Respondents surveyed in Phase 2 were significantly more likely to perceive changes in their long-term outdoor recreation behaviors than those surveyed during Phase 1 (Table 21). This indicates that as behaviors continue to be altered due to COVID-19, the likelihood of longterm changes is likely to increase in response. Of the specific behaviors included in the surveys, travelling further to recreate and changing types of outdoor recreation were rated significantly higher in Phase 2 (Table 22).

\section{Literature Cited.}

Green, G.T., J.M. Bowker, X. Wang, H.K. Cordell, \& Johnson, C.Y. (2009). An examination of perceived constraints to outdoor recreation. Journal of Public Affairs and Issues, 12, 28-53

Hammitt, W.E., Backlund, E.A., \& Bixler, R.D. (2004). Experience use history, place bonding and resource substitution of trout anglers during recreation engagements. Journal of Leisure Research, 36(3), 356-378

Harper, E. E., Miller, C. A., \& Vaske, J. J. (2015). Hunter perceptions of risk, social trust, and management of chronic wasting disease in Illinois. Human Dimensions of Wildlife, 20(5), 394-407.

Heberlein, T.A. (2012). Navigating environmental attitudes. Oxford, UK: Oxford University Press.

Kuo, M. (2015). How might contact with nature promote human health? Promising mechanisms and a possible central pathway. Frontiers in Psychology, 6, 1-8.

Marion, J.L., \& Reid, S.E. (2007). Minimising visitor impacts to protected areas: The efficacy of low impact education programmes. Journal of Sustainable Tourism, 15(1), 5-27.

Reis, A.C., Thompson-Carr, A., \& Lovelock, B. (2012). Parks and families: Addressing management facilitators and constraints to outdoor recreation participation. Annals of Leisure Research, 15(4), 315-334

Rice, W. L., Meyer, C., Lawhon, B., Taff, B. D., Mateer, T., Reigner, N., \& Newman, P. (2020, April 18). The COVID-19 pandemic is changing the way people recreate outdoors: Preliminary report on a national survey of outdoor enthusiasts amid the COVID-19 pandemic. https://doi.org/10.31235/osf.io/prnz9

University of Florida Tourism Crisis Management Initiative (2020). COVID-19 perceptions of travel risk survey. Retrieved from https://www.uftourism.org/covid-19-tcmi

U.S. Census Bureau (2010). 2010 urban area FAQs. Retrieved from https://www.census.gov /programs-surveys/geography/about/faq/2010-urban-area-faq.html

Vaske, J. J. (2008). Survey research and analysis: Applications in parks, recreation and human dimensions. State College, PA: Venture Publishing. 